\title{
Social Media for New Product Launch: A Study of Social Media Platforms Across the RACE Planning Framework
}

\author{
https://doi.org/10.3991/ijim.v15i05.18147 \\ Sonica Rautela \\ Symbiosis International (Deemed University), Pune, India \\ sonicaonnetegmail.com
}

\begin{abstract}
The world of marketing communication has been transformed completely by the presence of the internet and internet-enabled platforms. Today, the internet and related platform are home to massive amounts of human dialogues. Human interaction has changed drastically because of the presence of a wide variety of web-based platforms and the proliferation of media. Social Media- a Web 2.0 enabled platform has become an integral part of human life. Also, businesses have started actively participating in these platforms as they have found their users spending a substantial amount of time on these platforms. Thus, social media has become a part of digital marketing which involves the use of a wide variety of digital technologies and digital media to connect to the audience. The RACE i.e., the Reach Act Convert Engage digital marketing framework is a popular infographic, introduced to aid marketers to plan and manage the digital marketing related activities in a more organized manner. The present study aims at exploring the usage of social media at the launch or the commercialization phase of new product development. To fulfill this objective the study uses the RACE digital Planning framework. The study also aims at highlighting the most popular alternatives of social media in each category of the RACE Planning framework in the launch phase of NPD.
\end{abstract}

Keywords: Social Media, RACE Planning framework, Launch phase, New Product Development (NPD), Digital Marketing

\section{Introduction}

The Internet has metamorphosed the entire world of marketing communication. Today, it hosts a huge number of "human dialogue" which are mounting drastically [1] and unlocked to be viewed by anyone- anywhere in the World Wide Web (WWW) connected world. This revolution has been facilitated by a radical increase in the number of web-based platforms and the proliferation of media. Also, as can be observed human interaction has changed radically in the present digitally connected era resulting in an alteration in human activities, human interaction, and the realworld social relationship [2]. Interestingly, the social relationship between human beings have moved beyond geographical boundaries and has migrated to the world of virtual relationship where geographical, social, cultural boundaries do not play any role. 
Marketers today are fortunate because they have a wide variety of online tools and platforms to connect, co-create, and communicate in real-time with their customers [3]. These online tools and platforms are very useful in getting an insight of the customers and their changing habits, taste, and preferences. However, at the same time, it has also strengthened the position of customers. Customers in today's world are offered greater price transparency, chance to dictate prices [4], interact freely with marketers, put forward their likes/dislikes, satisfaction/dissatisfaction regarding a product, engage and co-create in different phases of new product development, give and take opinion to and from the entire world and so on. In other words, technology has changed people and their way of relating to products and markets. Reference [4] has termed these breeds of the customers as 'cyber-consumers'.

The emergence of digital marketing is one of the foremost changes in the world of marketing which has compelled the marketers to rethink their marketing strategies [5]. The rethinking and redesigning of marketing strategies are vital for the survival and competitiveness of the business firms in the new digital era. Digital Marketing for some traditional business firms and business owners means creating a website or a Facebook page. This thought process limits the scope of digital marketing and vital activities that need to be managed for successful digital marketing may be ignored or missed [6]. In other words, digital marketing is much more than having a website or a Facebook page.

Digital Marketing encompasses the usage of a wide variety of digital technologies and digital media to connect to the audience. One such web-enabled platform is social media. Social media is a Web 2.0 enabled platform that allows users to view, create, and share content generated by them. The domain of social media is much bigger than it seems to many of us [7]. Also, it is interesting to note that the domain of social media keeps on changing and the platforms (such as Facebook) which are skyrocketing currently may not be present (such as Orkut and MySpaces) tomorrow [8].

Social Media embraces multiple platforms like social networking sites (SNSs), social search, social knowledge-sharing platforms, social blogging, collaborative projects, chatting apps, social commerce, content communities, social bookmarking platforms, photo-sharing networks, business and lifestyle networks, and so on. Social Media has been increasingly used by the marketers to foster the relationship and development of a business network which facilitates innovation and achievement of business goals [9]. It provides multiple interactive platforms that promise enhanced communication and better collaboration within and outside an organization's boundaries [10]. This enhanced interaction provides a fertile ground for the development or co-creation of new products and services ideas which can be translated into future offerings of the firm. With the advent of these "co-creation technologies," the engagement of customers in value creation has enhanced [11]. Also, the process of new product development has changed radically and is not confined to the boundaries of the organization but has become more customer-centric and customer-oriented [12] [13].

Social Media and its role in NPD and co-creation is a growing field of inquisitiveness for researchers, marketers, and academicians. However, the in-depth review of past studies reveals that this area is still in its developing stage [13] and "just moving from the what question to the how question" [14]. Researchers and 
academicians in the past have studied the usage of social media as a platform for open innovation and customer participation [15] [16]. Few studies also highlight the important role social media can play in the process of new product development (NPD) [17], [18]. However, the past literature offers a limited number of studies which focuses on the use of social media for the launch or commercialization of new product [19]. The present study aims to bridge this gap and introduces popular categories of social media platforms available in the launch phase of NPD.

The above introduction leaves us to investigate the answer to the following research question.

\subsection{Research questions and aim of the study}

The present study is exploratory and aims at addressing the above gap and exploring the usage of social media at the launch or the commercialization phase of new product development. To fulfill this objective the study uses the RACE digital Planning framework. The purpose of the study can be summarized in the following research question:

RQ1: What are the most popular alternatives of social media in each category of the RACE Planning framework in the launch or the commercialization phase of NPD?

The remainder of the paper is structured as follows: the paper begins with reviewing the literature relevant to the present area of study, secondly, it highlights the usage of social media in the launch phase of NPD across the RACE planning framework followed by a conceptual model. The paper closes with the conclusion and scope for future study.

\section{$2 \quad$ Literature Review}

The following sections present the literature review related to digital marketing, Digital Marketing, and Social Media, Social Media and the launch phase of NPD and the RACE Digital Marketing Planning Framework which are of interest to the present study.

\subsection{Digital marketing}

The term "digital marketing" has evolved with time [20] and is also referred to as Internet Marketing, E-Marketing, or Web marketing in the past literature by different academicians, researchers, and professionals. The usage of these words has varied over time. This is also depicted from Google Trends [21] which is plotted from the year 2004 to the present year 2020 (Figure 1). As can be comprehended from figure 1 the term digital marketing is the most frequently used term worldwide. 


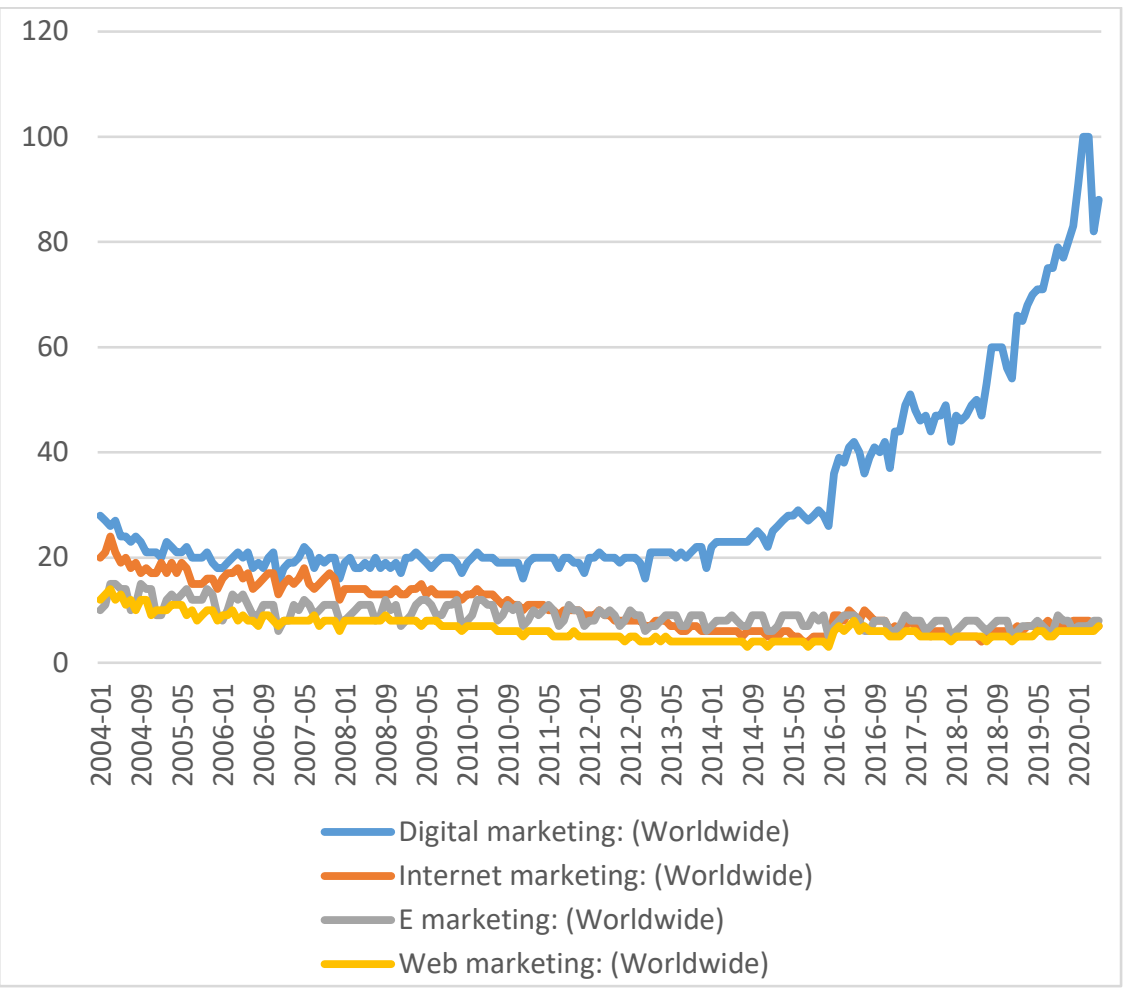

Fig. 1. Usage of different terms related to digital marketing from the year 2004 to the year 2020 (Google Trends, 2020)

Digital marketing is a type of marketing where the digital medium is used to promote products and services and to reach the target population [22] Reference [23] defines digital marketing as:

"Achieving marketing objectives through applying digital technologies and media".

As per the American Marketing Association (AMA) [24], digital marketing is:

"The use of digital or social channels to promote a brand or reach consumers. The kind of marketing can be executed within social media, search engines, the internet, mobile devices, and other channels. It requires new ways of marketing to consumers and understanding the impact of their behavior".

Digital marketing embraces all the activities involved in managing an online firm's presence such as the website of the firm, social media pages, mobile apps, search engine marketing, online advertising, e-mail marketing, etc. However, the integration of digital media with traditional media is still necessary for the success of digital marketing [6]. The real-time analysis of content, campaign, and strategy is possible because of the usage of multiple channels and technologies. In other words, the organization can monitor what is working and what is not working in real-time [25] and can alter their marketing strategies accordingly. 
One of the most important characteristics that differentiate the digital media marketing environment from a traditional media marketing environment is the possibility and ease of two-way communication. Communication can happen between customers and firms as well as among customers. Also, the communication between the customers is now not restricted to family, friends, or known individuals but also have extended to unknown customers across the globe [20]. Digital Media has empowered customers while at the same time have provided firms with an opportunity to become part and parcel of the customer decision making process. Firms can help customers in identifying, learning, evaluating choices, and making smart choices [26]. To a large extent, this has been possible because of the evolution and use of social media. Social media is a highly interactive medium present in today's world. As modern interactive marketing demands for deeper customer understanding [1], it becomes vital for firms to engage customers via platforms that promise better reach, connectivity, creativity, co-creation, and collaboration. Social Media serves the purpose effectively and efficiently.

\subsection{Digital marketing and social media}

Digital Marketing involves the use of various digital channels. One such channel is social media. Social Media are the Web 2.0 based applications that enable and enhances the marketing efforts of the firms [2]. Social Media permits firms to implement communication forms which are novel and innovative, helps firms to collaborate and co-create with their customers, engages customers and helps in enhancing the satisfaction level of customer and humanizes the entire process of communication.

Firms can't afford to ignore the power of social media. This is because social media has a huge user base. The estimated number of active social media users worldwide in 2019 was 2.95 billion. This number is expected to reach 3.43 billion by the year 2023 which is surprisingly a third of the earth's total population. Also, the users from China and India will constitute the major slice of the total active social media user's population with 800 million users from China and 450 million users from India [27]. In other words, the usage of social media is "a must" for today's business firms [28]

Reference [2], in their study, emphasized that in today's digitally connected world firms faces pressure to adopt social media platforms. The pressure is both from external as well as internal environment. External forces include usage by competitors, the drastic increase in the numbers of customers present in social media platforms (due to various benefits), active participation by customers, changes in the technological environment. Internal forces include an increase in efficiency due to usage of social media, effective tool for market research and customer relationship management, support in making process, better understanding of customer needs, support to marketing, sales, and Research and Development (R and D) department and better target market coverage at low prices.

With the advent of smartphones and other mobile devices, customers are connected digitally anytime and anywhere. Worldwide the total number of smartphone users has surpassed the 3 billion mark and is projected to grow by quite a few hundred million in the coming few years [27]. The growth in the usage of these mobile devices has 
accelerated the growth of social media and has also led to the growth of multiple social media applications [29]. Social media brings massive opportunities for firms in multiple sectors. The present paper tries to present an insight into the usage of social media in the launch phase of the new product. The study highlights the most popular alternatives of social media in each category of the RACE Planning framework in the launch phase of new product development.

\subsection{Social media and the launch phase of new product}

Development and introduction of new product in the market is vital in the growth story of any firm. The new product provides a fresh set of hopes to the business firms in this dynamic marketplace. A new product has multiple dimensions and perspectives involved. For a few new products are correcting the mistakes in existing products, for others, the new product is a "me too" product similar to what is introduced by the competitor. Few defines a new product as a means of giving altogether new experience to the customer. A new product is also about breaking the clutter and differentiating your product from other competitors.

The final stage in the development of a new product is the launch or commercialization. This stage involves decision making related to the timing of the launch, decision-related to the geographical region where the product will be first launched, who will be the first prospective customers to be targeted, strategies related to marketing communication, branding, launching, promotion, etc. are decided [30]. Most of the information needed in this phase is however accumulated throughout the entire new product development (NPD) process [31].

According to [32], the launch stage of NPD often drives the firm's business performance and is expensive in most of the cases. Reference [33] shared their concern related to the negligence of this important stage in the case of many product launches. According to these researchers, firms are often so much engrossed in the design and development phase that they fail to provide adequate attention to this key stage of NPD. Also, this is the phase where consumers come in contact with the final product for the first time and share their experiences, concerns, feedback, like/dislike with other customers and with the firm. Despite being one of the critical stages in the new product development process, research in the area of new product launch is infantile [19], [34].

In today's web-connected world, the experiences, feedback, and concerns of the customers are shared on various social media platforms. Social media, therefore, enables "social interaction and online word-of-mouth" communication which results in diffusion of information related to the new product at a faster pace [35]. Reference [19] was of the view that social networking sites (SNSs) present an important opportunity for marketers for the launch of new products. However, understanding SNSs user's motivation to engage online can aid firms in recognizing "potentially valuable users" and in developing a "more strategic and targeted approach to New Product Launch". Reference [17] opined the formal use of social media in NPD so that better insights of consumer needs can be generated which can be converted into information for future NPD processes. 


\subsection{The RACE digital marketing planning framework}

The RACE digital marketing framework is a popular infographic introduced by [36]. This framework was introduced to aid marketers to plan and manage the digital marketing related activities in a more organized manner. This framework was updated in the year 2020 and includes key target areas as well as key measures to evaluate performance at every stage of the framework [6].

There are five distinct stages in the RACE digital marketing planning framework. These are - Plan, Reach, Act, Convert, and Engage. The last four stages form the acronym RACE. In few instances this model is also called PRACE however the acronym RACE is much popular in usage [6]. The following section presents an insight into these stages:

Plan: The initial stage of the model is the 'Planning' stage. This stage involves three interrelated steps: analysis of the situation, objective setting, and formulation of the strategy [3]. The analysis of the situation deals with both internal and external environment analysis. It is vital for firms to thoroughly understand its strengths and weakness, external forces such as political, social, cultural, legal, economic environment, competitors, customers, etc. affecting the firm directly or indirectly. This analysis helps the firm in designing its objective and framing its business strategy.

Reach: The next stage is 'Reach' which involves reaching out to the target population. This is the stage were the main focus of the firm is to create awareness about its products and offerings. In this step, a firm uses multiple interfaces with the target population which can be created by paid, earned, or owned media. The main objective is to build traffic to the firm's main website or to a social media page [6].

Act: The stage of 'Reach' is followed by 'Act' which involves persuading the target population or audiences to act in a positive way toward firms' offerings. It is used as a short form for 'Interact' [6]. Interaction is one of the imperative drivers of success in today's digitally connected world. This interaction is a powerful medium to drive the audience's engagement with products, services, brands offered by the firm. However, keeping audience engagement quotient high is one of the most challenging tasks in the entire process of digital marketing. This requires high and active involvement from the part of the firm [37]. Also, the vividness, interactivity, and entertaining property of the firm generated content plays a vivacious role in enhancing the interaction and then engagement with the prospective customers [38].

Convert: The stage following the 'act' stage is the 'Convert' stage. This is the stage where the audience takes a vital step in getting converted into paying customers. This can happen via online or offline tractions with the customers.

Engage: The final stage is the 'Engage' stage. This is the ultimate aim of any business firm. Long-term engagement of the firm with its customers is vital for the sustainable and healthy growth of any firm. This stage is also referred to as 'Resonance' in Keller's Brand Equity Model or the Consumer-Based Brand Equity (CBBE) Model This engagement also results in repeat purchase and free advocacy of a firm's product by the customers, a key contributor to the firm's profitability and growth. 


\section{$3 \quad$ Research Methodology}

The present study is exploratory and is based on secondary data. The main focus of the present study is the review and synthesis of a range of social media platforms available within the existing literature and which can be used in the launch phase of NPD. The secondary data was collected from various databases like EBSCO, JSTOR, SCOPUS, etc., books, webpages, and related documents. This secondary data was gathered and used for literature review and to get an insight into the past studies related to the topic.

\section{Usage of Social Media in The Launch Phase of NPD Across the RACE Planning Framework}

Social Media is much more than being an "Evolution of Web-based technologies". It has created a social revolution and transformed the ways of human interaction and communication [2]. Social media promises a free flow of information without any physical, social, and geographical boundaries. It has provided customers and firms a platform to interact, communicate, view create and share content, express their viewpoints, share opinions and feedback on subjects of interest. Firms can successfully use social media in the launch of new products. Utilizing social media in the launch phase provides twofold benefit to the business firms. Firstly, it acts as a tool to disseminate information to the customers through the use of various platforms. It promotes two-way communication between the firm and its customer. Secondly, it enhances positive word-of-mouth communication and customer involvement leading to an increase in sales and a higher adoption rate of the firm's offerings [13].

Also, the launch is the final and critical phase of the New Product Development (NPD) process. It is believed the successful launch and commercialization of the new product is the key driver of business performance [40], [41], [42]. The main goal of marketing communication in the launch of products is to inform, create awareness, produce interest, and persuade consumers to try new products [18]. The inherent nature of social media makes it a perfect platform that can be used to reach out, interact, persuade, and engage target audiences.

However, social media includes multiple platforms that differ in their scope as well as functionality [43]. Thus, there can be few social media platforms which can act as a wonderful tool to reach and inform target customers, others social media platforms can be used by the firms as a platform to interact with customers, while other platforms can persuade a customer to buy firm offerings and maintain a long-term relationship. Figure 2 depicts the essential and most popular social media platforms during the launch phase of NPD across the RACE Planning framework. 


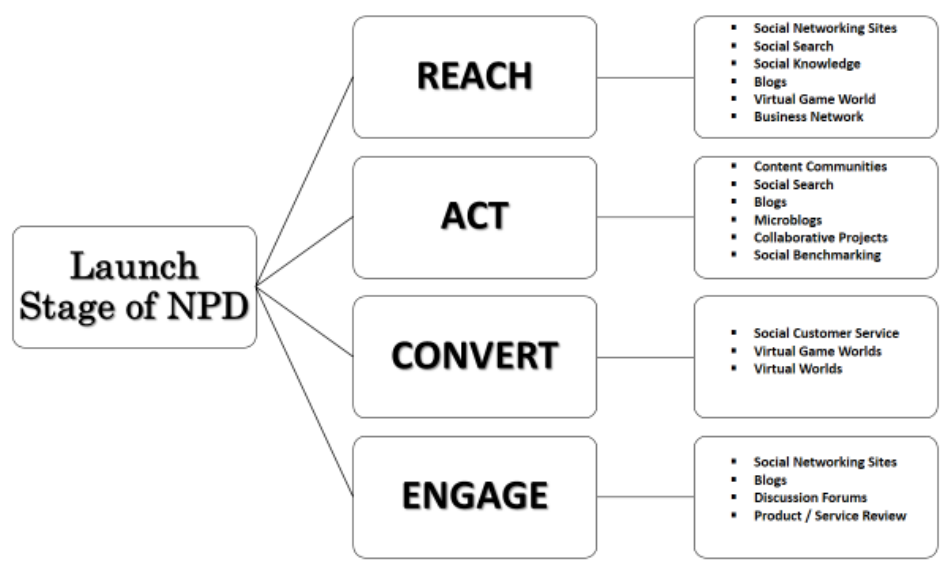

Fig. 2. Essential social media platforms during the launch phase across the RACE Planning framework (Author's Own)

The following sections present insights into the most popular alternatives of social media in each category of the RACE Planning framework.

\subsection{Social media platforms in the REACH stage of product launch}

The primary focus of any business firm, during the initial period of product launch, is to create awareness of the firm's products, brands, or offerings. In other words, any business firm tries to maximize its touch points with its target audience so that traffic is built towards its main website or webpage. Table 1 gives an overview of the social media platforms that can be used in the REACH stage of product launch.

Table 1. Social media platforms that can be used in the reach stage of product launch.

\begin{tabular}{|l|l|l|l|}
\hline $\begin{array}{c}\text { Social Media } \\
\text { Platforms }\end{array}$ & \multicolumn{1}{|c|}{ Characteristics } & Example & \multicolumn{1}{|c|}{ Role in Reach stage } \\
\hline $\begin{array}{l}\text { Social Networking } \\
\text { sites (SNSs) }\end{array}$ & $\begin{array}{l}\text { "Social network sites (SNSs) are the } \\
\text { most popular social media platforms } \\
\text { applications that enable users to } \\
\text { connect by creating personal } \\
\text { information profiles, inviting friends } \\
\text { and colleagues to have access to those } \\
\text { profiles, and sending e-mails and } \\
\text { instant messages between each other" } \\
\text { [37]. }\end{array}$ & $\begin{array}{l}\text { Google+, } \\
\text { Instagram }\end{array}$ & $\begin{array}{l}\text { Facebook, } \\
\text { provides firms with innovative } \\
\text { and interactive means of } \\
\text { communicating with customers } \\
\text { during the launch of a new } \\
\text { product. SNSs also increases } \\
\text { brand engagement and positive } \\
\text { word of mouth communication } \\
\text { regarding products/services after } \\
\text { launch. }\end{array}$ \\
\hline Social Search & $\begin{array}{l}\text { "Social search is an umbrella term } \\
\text { used to describe search acts that make } \\
\text { use of social interactions with others. } \\
\text { These interactions may be explicit or } \\
\text { implicit, co-located or remote, } \\
\text { synchronous, or asynchronous"[44]. }\end{array}$ & $\begin{array}{l}\text { Aardvark, } \\
\text { Bing, Google } \\
\text { Product } \\
\text { Search, } \\
\text { Google } \\
\text { places }\end{array}$ & $\begin{array}{l}\text { Firms can utilize these platforms } \\
\text { for deriving business and traffic } \\
\text { based on social graphs. }\end{array}$ \\
\hline
\end{tabular}




\begin{tabular}{|c|c|c|c|}
\hline Social Knowledge & $\begin{array}{l}\text { Social Knowledge is defined as the } \\
\text { virtual environment consisting of a } \\
\text { collective body of knowledge } \\
\text { produced by the community as a } \\
\text { whole. The important characteristic of } \\
\text { social knowledge is that it is not the } \\
\text { total of a group's knowledge rather it } \\
\text { is a product of the contributed } \\
\text { knowledge from the society as a } \\
\text { whole. }\end{array}$ & $\begin{array}{l}\text { Google } \\
\text { Scholar, } \\
\text { Research } \\
\text { Gate }\end{array}$ & $\begin{array}{l}\text { Firms offering products relevant } \\
\text { to the social knowledge group can } \\
\text { promote their product and reach } \\
\text { out to the target population. }\end{array}$ \\
\hline Blogs & $\begin{array}{l}\text { A blog (derived from the weblog) or } \\
\text { blogging is used as a synonym in } \\
\text { today's world to represent the creation } \\
\text { and sharing of content which is } \\
\text { generally longer. Blogs generally have } \\
\text { a chronological list of postings where } \\
\text { the recent post appears first. Blogs } \\
\text { based on the text are most common } \\
\text { than other forms of blogs [37]. The } \\
\text { visitors to the blog can read and } \\
\text { comment. Blogs can be run by both } \\
\text { individuals as well as business firms, } \\
\text { which use them to post information } \\
\text { related to a firm's product, new } \\
\text { product launch, or product tests. }\end{array}$ & $\begin{array}{l}\text { |loger, } \\
\text { Blogger } \\
\text { WordPress, } \\
\text { Tumblr }\end{array}$ & $\begin{array}{l}\text { Blogs can be used to increase } \\
\text { brand awareness and positive } \\
\text { word of mouth communication } \\
\text { related to products/services. In } \\
\text { today's world blog writers or } \\
\text { bloggers play a vital role in } \\
\text { influencing customer choices and } \\
\text { decisions related to brands and } \\
\text { products. }\end{array}$ \\
\hline $\begin{array}{l}\text { Virtual Game } \\
\text { Worlds }\end{array}$ & $\begin{array}{l}\text { In the case of virtual game worlds, } \\
\text { users can participate in a virtual game } \\
\text { where they can "appear in the form of } \\
\text { personalized avatars" and have to } \\
\text { follow certain rules. The user is not } \\
\text { limited to a particular geographical } \\
\text { boundary [37]. }\end{array}$ & $\begin{array}{l}\text { World of } \\
\text { Warcraft }\end{array}$ & $\begin{array}{l}\text { Virtual Games worlds can be used } \\
\text { for reaching the target audiences } \\
\text { by placing the product as a prop } \\
\text { in the game or by using in-game } \\
\text { advertising. }\end{array}$ \\
\hline $\begin{array}{l}\text { Business } \\
\text { Networks }\end{array}$ & $\begin{array}{l}\text { Business Networks are a professional } \\
\text { network that is designed to help } \\
\text { people make professional contact, find } \\
\text { a job, post resume, share their } \\
\text { experiences, and expert knowledge. } \\
\text { Users can register and create a } \\
\text { personal profile. They are also free to } \\
\text { share specific content. }\end{array}$ & LinkedIn & $\begin{array}{l}\text { Companies primarily use } \\
\text { professional networks to search } \\
\text { potential candidate for a job role } \\
\text { and position themselves as an } \\
\text { employer. However, platforms } \\
\text { like LinkedIn have been actively } \\
\text { used by individuals as well as } \\
\text { firms to post content related to the } \\
\text { firm's products, services offered, a } \\
\text { new product introduced, social } \\
\text { activity done by the corporates, } \\
\text { and so on. This helps in creating } \\
\text { awareness and positioning } \\
\text { themselves. }\end{array}$ \\
\hline
\end{tabular}

\subsection{Social media platforms in the ACT stage of product launch}

Interact ACT, the next stage of the RACE Digital Marketing Planning Framework involves engaging target audiences in various platforms to generate leads [6]. Interaction is important as it motivates and engages customers with the firm and its offerings. Social Media has been advocated as an excellent platform for such interaction by different academicians and researchers [19], [45], [46]. Also, the twoway interaction which is possible in the case of social media is what distinguishes 
social media from traditional media. In today's world, social media have been proved as cultivating a crucial relationship between firms and their customers [47], [48], and thus playing a pivotal role in persuading customers to move ahead in their buying decision journey. Table 2 gives an overview of the social media platforms that can be used in the ACT stage of product launch.

Table 2. Social media platforms that can be used in the Act stage of product launch.

\begin{tabular}{|c|c|c|c|}
\hline $\begin{array}{c}\text { Social Media } \\
\text { Platform }\end{array}$ & Characteristics & Example & Role in the ACT stage \\
\hline Content Communities & $\begin{array}{l}\text { Content communities facilitate the } \\
\text { sharing of multimedia content } \\
\text { between various users. Multimedia } \\
\text { content (in the form of video, text, } \\
\text { photos, PowerPoint presentations, } \\
\text { etc.) can be uploaded in different } \\
\text { content communities. }\end{array}$ & \begin{tabular}{|l|} 
YouTube \\
(Video), \\
Slide share \\
(PPT), \\
Flickr \\
(Photos), \\
iTunes \\
(Music)
\end{tabular} & $\begin{array}{l}\text { It can be used to create } \\
\text { awareness, interaction, and } \\
\text { persuading customers. }\end{array}$ \\
\hline Social Search & $\begin{array}{l}\text { "Social search is an umbrella term } \\
\text { used to describe search acts that make } \\
\text { use of social interactions with others. } \\
\text { These interactions may be explicit or } \\
\text { implicit, co-located or remote, } \\
\text { synchronous, or asynchronous"[44]. }\end{array}$ & $\begin{array}{l}\text { Aardvark, } \\
\text { Bing, } \\
\text { Google } \\
\text { Product } \\
\text { Seach, } \\
\text { Google } \\
\text { places }\end{array}$ & $\begin{array}{l}\text { Firms can utilize these platforms } \\
\text { for giving information and } \\
\text { building traffic towards their } \\
\text { main webpage. }\end{array}$ \\
\hline Blogs & $\begin{array}{l}\text { A blog (derived from the weblog) or } \\
\text { blogging is used as a synonym in } \\
\text { today's world to represent the } \\
\text { creation and sharing of content which } \\
\text { is generally longer. Blogs generally } \\
\text { have a chronological list of postings } \\
\text { where the recent post appears first. } \\
\text { Text-based blogs are most common } \\
\text { than other forms of blogs [37]. The } \\
\text { visitors to the blog can read and } \\
\text { comment. Blogs can be run by both } \\
\text { individuals as well as business firms, } \\
\text { which use them to post information } \\
\text { related to a firm's product, new } \\
\text { product launch, or product tests. }\end{array}$ & \begin{tabular}{|l|} 
Blogger, \\
WordPress, \\
Tumblr \\
\end{tabular} & $\begin{array}{l}\text { Blogs can be used to increases } \\
\text { brand awareness and positive } \\
\text { word-of-mouth communication } \\
\text { related to products/services. In } \\
\text { today's world blog writers or } \\
\text { bloggers play a vital role in } \\
\text { influencing customer choices } \\
\text { and decisions related to } \\
\text { products. Blogging can motivate } \\
\text { customers to try products } \\
\text { offered by the firm. }\end{array}$ \\
\hline Microblogs & $\begin{array}{l}\text { In contrast to blogs, microblogs } \\
\text { restrict the size of the } \\
\text { communication. Users can share text, } \\
\text { pictures, and web links. }\end{array}$ & Twitter & $\begin{array}{l}\text { Firms can use microblogs to } \\
\text { persuade users to subscribe to } \\
\text { news related to the firm or to } \\
\text { share web links related to the } \\
\text { firm's products leading to an } \\
\text { increase in traffic to the firm's } \\
\text { main webpage. }\end{array}$ \\
\hline Collaborative Projects & $\begin{array}{l}\text { These social media platforms enable } \\
\text { the collaboration between many end- } \\
\text { users and the simultaneous creation } \\
\text { of content. The users are free to edit } \\
\text { or change i.e., delete/add/remove } \\
\text { content [37]. }\end{array}$ & Wikipedia & $\begin{array}{l}\text { It can be used to create } \\
\text { awareness, interaction, and } \\
\text { persuading customers. }\end{array}$ \\
\hline
\end{tabular}




\begin{tabular}{|l|l|l|l|}
\hline Social Bookmarking & $\begin{array}{l}\text { Social bookmarking is an online } \\
\text { service that enables users to save and } \\
\text { organize web documents so that they } \\
\text { can share them with other users. } \\
\text { Social Bookmarks provide a central } \\
\text { platform to its users and is a valuable } \\
\text { indicator of popular websites and } \\
\text { other web documents or content [49]. }\end{array}$ & $\begin{array}{l}\text { Delicious, } \\
\text { Pinterest, } \\
\text { Reddit }\end{array}$ & $\begin{array}{l}\text { It can be used to create } \\
\text { awareness, interaction, and } \\
\text { persuading customers. }\end{array}$ \\
\hline
\end{tabular}

\subsection{Social media platforms in the CONVERT stage of product launch}

The next stage following ACT is CONVERT which is that vital stage which converts a prospective audience into a revenue-generating customer. Social Media platforms can help in converting prospects into customers. Table 3 gives an overview of the social media platforms that can be used in the CONVERT stage of product launch.

Table 3. Social media platforms that can be used in the convert stage of product launch.

\begin{tabular}{|c|c|c|c|}
\hline $\begin{array}{l}\text { Social Media } \\
\text { Platform }\end{array}$ & Characteristics & Example & Role in Convert stage \\
\hline $\begin{array}{l}\text { Social Customer } \\
\text { Service }\end{array}$ & $\begin{array}{l}\text { The act of providing customer service via } \\
\text { social media platforms is referred to as } \\
\text { social customer service. The activities } \\
\text { included are answering queries of } \\
\text { customers, addressing concerns, } \\
\text { educating, and providing online guidance } \\
\text { of the firm's products, and issuing } \\
\text { refunds via social channels. }\end{array}$ & $\begin{array}{l}\text { TeamNike, } \\
\text { SpotifyCares }\end{array}$ & $\begin{array}{l}\text { Social customer service is } \\
\text { an affordable alternative to } \\
\text { other forms of customer } \\
\text { service. While addressing } \\
\text { the concern of one } \\
\text { customer, the conversation } \\
\text { might be witnessed by } \\
\text { other users also. This sends } \\
\text { a positive message to the } \\
\text { entire user group who are } \\
\text { witnessing the online } \\
\text { conversation. This } \\
\text { reinforces the feeling of } \\
\text { being wanted and cared for } \\
\text { by the firm [50]. This will } \\
\text { lead to the conversion rate. }\end{array}$ \\
\hline Virtual Game Worlds & $\begin{array}{l}\text { In the case of virtual game worlds, users } \\
\text { can participate in a virtual game where } \\
\text { they can "appear in the form of } \\
\text { personalized avatars" and have to follow } \\
\text { certain rules. The user is not limited to a } \\
\text { particular geographical boundary [37]. }\end{array}$ & $\begin{array}{l}\text { World of } \\
\text { Warcraft }\end{array}$ & $\begin{array}{l}\text { Virtual Games worlds can } \\
\text { be used for reaching the } \\
\text { target audiences by placing } \\
\text { the product as a prop in the } \\
\text { game or by using in-game } \\
\text { advertising. }\end{array}$ \\
\hline Virtual Worlds & $\begin{array}{l}\text { Virtual worlds are 'computer-based } \\
\text { simulated environment' populated by } \\
\text { users who are intended to live and } \\
\text { interact in the form of a virtual persona } \\
\text { also referred to as 'Avatars'. The users } \\
\text { can participate in all the activities or } \\
\text { communicate with others in the form of } \\
\text { avatars [51]. Virtual worlds allow users } \\
\text { to interact in real-time and do not have } \\
\text { any restrictions on the behavior or way of } \\
\text { interaction [52]. }\end{array}$ & Second Life & $\begin{array}{l}\text { Most of the virtual worlds } \\
\text { use virtual currencies, } \\
\text { which have an actual } \\
\text { value, and permit firms to } \\
\text { sell virtual or real products } \\
\text { [45]. Thus, converting the } \\
\text { potential audience into } \\
\text { paying customers. }\end{array}$ \\
\hline
\end{tabular}




\subsection{Social media platforms in the ENGAGE stage of product launch}

The final stage of the RACE Digital Marketing Planning Framework is to ENGAGE. Engagement with the customer is vital for the sustainability and health of any organization. Long term relationships with the customer should be the ultimate goal of any business firm. Firms can use social media to engage with the customer. Table 4 gives an overview of the social media platforms that can be used in the ENGAGE stage of product launch.

Table 4. . Social media platforms that can be used in the engage stage of Product Launch.

\begin{tabular}{|c|c|c|c|}
\hline $\begin{array}{l}\text { Social Media } \\
\text { Platform }\end{array}$ & Characteristics & Example & Role in Engage stage \\
\hline $\begin{array}{l}\text { Social Networking } \\
\text { Sites }\end{array}$ & \begin{tabular}{|l|} 
"Social network sites (SNSs) \\
are the most popular social \\
media platforms applications \\
that enable users to connect by \\
creating personal information \\
profiles, inviting friends and \\
colleagues to have access to \\
those profiles, and sending e- \\
mails and instant messages \\
between each other" [37]. \\
\end{tabular} & $\begin{array}{l}\text { Facebook, } \\
\text { Google+, } \\
\text { Instagram }\end{array}$ & $\begin{array}{l}\text { Social Networking Sites (SNSs) } \\
\text { provides firms with innovative } \\
\text { and interactive means of } \\
\text { communicating with customers } \\
\text { during the launch of a new } \\
\text { product. SNSs also increases } \\
\text { brand engagement and positive } \\
\text { word of mouth communication } \\
\text { regarding products/services after } \\
\text { launch. }\end{array}$ \\
\hline$B \log s$ & \begin{tabular}{|l|} 
A blog (derived from the \\
weblog) or blogging is used as \\
a synonym in today's world to \\
represent the creation and \\
sharing of content which is \\
generally longer. Blogs \\
generally have a chronological \\
list of postings where the recent \\
post appears first. Text-based \\
blogs are most common than \\
other forms of blogs [37]. The \\
visitors to the blog can read \\
and comment. Blogs can be run \\
by both individuals as well as \\
business firms, which use them \\
to post information related to a \\
firm's product, new product \\
launch, or product tests. \\
\end{tabular} & $\begin{array}{l}\text { Blogger, } \\
\text { WordPress, } \\
\text { Tumblr } \\
\\
\\
\\
\end{array}$ & $\begin{array}{l}\text { Blogs can be used to increases } \\
\text { brand awareness and positive } \\
\text { word-of-mouth communication } \\
\text { related to products/services. In } \\
\text { today's world blog writers or } \\
\text { bloggers play a vital role in } \\
\text { influencing customer choices and } \\
\text { decisions related to products. } \\
\text { Blogging can motivate customers } \\
\text { to try products offered by the } \\
\text { firm. }\end{array}$ \\
\hline Discussion Forums & $\begin{array}{l}\text { Discussion forums are a virtual } \\
\text { platform where users are free to } \\
\text { ask and/or answer other users' } \\
\text { questions. Users can actively } \\
\text { exchange opinions, concerns, } \\
\text { and experiences with other } \\
\text { users. Usually, these } \\
\text { discussions can be assessed by } \\
\text { anyone. }\end{array}$ & Quora & $\begin{array}{l}\text { Firms can use discussion forums } \\
\text { to address the question related to } \\
\text { product usage, benefits, } \\
\text { availability, and so on. Also, } \\
\text { concerns shared by the users can } \\
\text { be addressed and solved by the } \\
\text { firm. The firms can use discussion } \\
\text { form to actively engage customers } \\
\text { with meaningful communication } \\
\text { related to firms, their brand, and } \\
\text { offerings. }\end{array}$ \\
\hline
\end{tabular}




\begin{tabular}{|c|c|c|c|}
\hline $\begin{array}{l}\text { Product / Service } \\
\text { Reviews }\end{array}$ & $\begin{array}{l}\text { These sites provide information } \\
\text { related to the product. Reviews } \\
\text { related to the offering of the } \\
\text { firm can be shared by the users. } \\
\text { These reviews are based on } \\
\text { certain criteria such as } \\
\text { perceived quality, price, etc. }\end{array}$ & Amazon & $\begin{array}{l}\text { Firms can see the reviews and } \\
\text { comments shared by the users. } \\
\text { They can address the concern and } \\
\text { take immediate action. By } \\
\text { resolving the issues, the firm can } \\
\text { enhance goodwill as well as build } \\
\text { a relationship with the users in the } \\
\text { long term. }\end{array}$ \\
\hline
\end{tabular}

\section{Conclusion and Implication for Managers}

The world of social media is dynamic and keeps on changing. However, the importance and power of social media cannot be ignored in today's digitally connected world. Social media has changed the entire world of communication [53], [54]. Social Media provides firms with a platform where it can directly engage with its final user with greater efficiency and comparatively at a low cost. Also, social media can be leveraged in multiple manners by the firm. As a tool for marketing communication, social media enhances the reach of the firm to the wider audiences and when used during the launch phase of the new product it can play a vital role. Also, with social media been deeply enrooted into the day-to-day life of users, it becomes important to understand its usage in various aspects of NPD and commercialization. The present study aims to understand the usage of social media at the launch or the commercialization phase of new product development.

Also, the RACE digital Planning framework was used to highlight the most popular alternatives of social media in each category of the RACE Planning framework in the launch phase of NPD. The present study opens the door for future studies also. Researchers in the future can add to the present list of social media platforms and can study in detail the use of each platform in the organizations. Also, the usage of social media in a different industry, their relevance, and practical implication can be studied in greater detail. Armed with the knowledge of various alternatives available, managers can plan to create and execute the new product launch campaigns with better competency and efficiency. Managers can choose from the alternatives discussed in the present research paper and use them according to their needs and preferences.

\section{$6 \quad$ Limitation}

Despite presenting insights of the most popular alternatives of social media in each category of the RACE Planning framework in the launch phase of NPD, the present study have few limitations. These limitations however also present the scope for future research work. First, the study is exploratory, and therefore empirical evidences are not part of the present study. Second, the study tries to summarize the most popular social media alternatives, however, researchers can add to the list many more options in the near future. Also, the option may vary from firm to firm. Third, the study is confined to the new product launch and therefore does not include other vital 
stages of NPD. Future studies can explore the social media options available and applicable to other stages of NPD.

\section{$7 \quad$ References}

[1] M. D. Stone and N. D. Woodcock, "Interactive, direct and digital marketing", Journal of research in interactive marketing. vol. 8 no. 1, pp. 4-17, 2014.

[2] M. Tiago and J. Veríssimo, "Digital marketing and social media: Why bother?" Business Horizons, vol. 57, no. 6, pp. 703- 708, 2014. Available: https://doi.org/10.1016/j. bushor.2014.07.002

[3] N Drokina, "Essential digital marketing tools across the race planning framework", Economics and Law, vol. 5, no.16, pp. 124-31, 2018.

[4] Wind and V. Mahajan, "Digital Marketing", Symphonya. Emerging Issues in Management, no. 1, pp.43-54, 2002. Available: https://doi.org/10.4468/2002.1.04wind.mahajan

[5] L. Baltes, Bulletin of the Transilvania University of Brasov. Economic Sciences. Series V, vol. 8, no.2, pp. 111, 2015

[6] D. Chaffey, "What is Digital Marketing? A visual summary - Smart Insights", Smart Insights, 2020. [Online]. Available: https://www.smartinsights.com/digital-marketingstrategy/what-is-digital-marketing/ https://doi.org/10.1142/9789811216985_0002

[7] S. Rautela and T. Singhal, "Deconstructing the Seven Cs of Social Media: A Summative Perspective", International Journal of Interactive Mobile Technologies (iJIM), vol. 14, no. 03, p. 179, 2020. Available: https://doi.org/10.3991/ijim.v14i03.10490

[8] L.L. Evans, Social Media Marketing: Strategies for Engaging in Facebook, Twitter and other Social Media. Pearson Education India, 2011.

[9] G. C. de Zubielqui and J. Jones, "How and when social media affects innovation in startups. A moderated mediation model", Industrial Marketing Management, vol. 85, pp. 209220, 2020. https://doi.org/10.1016/j.indmarman.2019.11.006

[10] S. Andriole, "Business impact of Web 2.0 technologies", Communications of the ACM, vol. 53, no. 12, pp. 67-79, 2010. Available: 10.1145/1859204.1859225.

[11] N. Holdgaard and L. Klastrup, "Between control and creativity: challenging co-creation and social media use in a museum context", Digital Creativity, vol. 25, no.3, pp.190-202, 2014. https://doi.org/10.1080/14626268.2014.904364

[12] H. Zhang, S. Gupta, W. Sun and Y. Zou, "How social-media-enabled co-creation between customers and the firm drives business value? The perspective of organizational learning and social Capital", Information and Management, vol. 57, no.3, 2020. https://doi.org/10. 1016/j.im.2019.103200

[13] Y. Rashid, A. Waseem, A. A. Akbar and F. Azam, "Value co-creation and social media", European Business Review, 2019. https://doi.org/10.1108/ebr-05-2018-0106

[14] A. Martini, S. Massa and S. Testa, "The role of social software for customer co-creation: does it change the practice for innovation?", International Journal of Engineering Business Management, vol.4, no.40, pp.1-10, 2012. https://doi.org/10.5772/54750

[15] F.A. Geise, "Integration of Consumers into New Product Development by Social MediaBased Crowdsourcing- Findings from the Consumer Goods Industry in Germany", Advances in Advertising Research, Springer Gabler, Wiesbaden, Vol. 7, pp. 15-2, 2017. https://doi.org/10.1007/978-3-658-15220-8_2

[16] F. Piller, A. Vossen and C. Ihl, "From Social Media to Social Product Development: The Impact of Social Media on Co-Creation of Innovation", Die Unternehmung, vol. 66, no. 1, pp. 7-27, 2012. Available: https://doi.org/10.5771/0042-059x-2012-1-7 
[17] N. Bashir, K. Papamichail and K. Malik, "Use of Social Media Applications for Supporting New Product Development Processes in Multinational Corporations", Technological Forecasting and Social Change, vol. 120, pp. 176-183, 2017. Available: https://doi.org/10.1016/j.techfore.2017.02.028

[18] N. Bashir, N. Papamichail, "Exploring the Role of Social Network Sites in New Product Development: An Empirical Study of MNCs", International Conference on Enterprise Marketing and Globalization (EMG). Proceedings, pp. 57-66, 2016.

[19] D. L. Roberts, M. Candi and M. Hughes, "Leveraging social network sites for new product launch", Industrial Management \& Data Systems, vol. 117, no. 10, pp. 2400-2416, 2017. Available: 10.1108/imds-11-2016-0472. https://doi.org/10.1108/imds-11-2016-0472

[20] P. K. Kannan and H. Li, "Digital marketing: A framework, review and research agenda", International Journal of Research in Marketing, vol. 34, no. 1, pp. 22-45, 2017. https://doi.org/10.1016/j.ijresmar.2016.11.006

[21] Google trends, 2020 Retrieved from https://trends.google.com/trends/ [Accessed: 18- May2020]

[22] A. Yasmin, S. Tasneem and K. Fatema, "Effectiveness of Digital Marketing in the Challenging Age: An Empirical Study", The International Journal of Management Science and Business Administration, vol. 1, no. 5, pp. 69-80, 2015. Available: https://doi.org/10.18775/ijmsba.1849-5664-5419.2014.15.1006

[23] D Chaffey, Digital marketing. Pearson UK, 2019.

[24] American Marketing Association (AMA) Retrieved from https://www.ama.org/topics /digital-marketing/[Accessed: 18- Jan- 2020]

[25] SAS Insights https://www.sas.com/en_us/insights/marketing/digital-marketing.html [Accessed: 10- Jan- 2020]

[26] D. C. Edelman, "Four ways to get more value from digital marketing", McKinsey Quarterly, vol.6, pp. 1-8, 2010

[27] J. Clement, "Social media - Statistics \& Facts Statista", [Online]. Available https://www.statista.com/topics/1164/social-networks/[Accessed: 12- Feb- 2020]

[28] S. Ainin, F. Parveen, S. Moghavvemi, N. Jaafar and N. Mohd Shuib, "Factors influencing the use of social media by SMEs and its performance outcomes", Industrial Management \& Data Systems, vol. 115, no. 3, pp. 570-588, 2015. Available: https://doi.org/10.1108/imds-07-2014-0205

[29] M. Yadav, Y. Joshi and Z. Rahman, "Mobile Social Media: The New Hybrid Element of Digital Marketing Communications", Procedia - Social and Behavioural Sciences, vol. 189, pp. 335-343, 2015. Available: https://doi.org/10.1016/j.sbspro.2015.03.229

[30] P. Kotler and K.L. Keller, K. L., Marketing management, Global edition. Pearson Education UK, 2016.

[31] M. Baker, and S. Hart, Product strategy and management. (2nd ed.). Pearson Education India, 2016

[32] D. Roberts and M. Candi, "Leveraging Social Network Sites in New Product Development: Opportunity or Hype?", Journal of Product Innovation Management, vol. 31, pp. 105-117, 2014. Available: https://doi.org/10.1111/jpim.12195

[33] J. Schneider and Hall, J. "Why most product launches fail”, Harvard Business Review, pp. 21-23, April 2011

[34] R.J. Calantone and C.A. Di Benedetto, C.A., "Clustering new product launches by price and launch strategy", Journal of Business and Industrial Marketing, vol. 22 no. 1, pp. 419, 2007. https://doi.org/10.1108/08858620710722789 
[35] Baum, D., Spann, M., Füller, J., \& Thürridl, C. (2019). The impact of social media campaigns on the success of new product introductions. Journal of Retailing and Consumer Services, 50, 289-297. https://doi.org/10.1016/j.jretconser.2018.07.003

[36] D. Chaffey and D. Bosomworth, Digital marketing: \#infographics to inspire your marketing and help planning, 2012. [Online]. Available: http://www.carmichaelcentre.

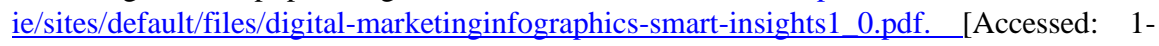
Feb- 2020]

[37] A. M. Kaplan and M. Haenlein, "Users of the world, unite! The challenges and opportunities of Social Media", Business Horizons, vol. 53, no. 1, pp. 59-68, 2010. Available: https://doi.org/10.1016/j.bushor.2009.09.003

[38] L. de Vries, S. Gensler and P. Leeflang, "Popularity of Brand Posts on Brand Fan Pages: An Investigation of the Effects of Social Media Marketing", Journal of Interactive Marketing, vol. 26, no. 2, pp. 83-91, 2012. Available: 10.1016/j.intmar.2012.01.003 [Accessed 8 July 2020]. https://doi.org/10.1016/j.intmar.2012.01.003

[39] K. L Keller, M. G. Parameswaran, and I. Jacob. Strategic brand management: Building, measuring, and managing brand equity. Pearson Education India, 2011.

[40] Bruce, M., L. Daly, and K. B. Kahn. 2007. "Delineating design decisions that influence the global product launch process", Journal of Product Innovation Management, vol. 24, no.5, pp. 456-470, 2007. https://doi.org/10.1111/j.1540-5885.2007.00263.x

[41] C.A. Benedetto, "Identifying the Key Success Factors in New Product Launch", Journal of Product Innovation Management, vol. 16, no. 6, pp. 530-544, 1999. Available: https://doi.org/10.1016/s0737-6782(99)00014-4

[42] E.J. Hultink, A. Griffin, S. Hart and H. Robben, "Industrial New Product Launch Strategies and Product Development Performance", Journal of Product Innovation Management, vol. 14, no. 4, pp. 243-257, 1997. Available: https://doi.org/10.1111/1540$\underline{5885.1440243}$

[43] G. Kane, M. Alavi, G. Labianca and S. Borgatti, "What's Different about Social Media Networks? A Framework and Research Agenda", MIS Quarterly, vol. 38, no. 1, pp. 274304, 2014. Available: https://doi.org/10.25300/misq/2014/38.1.13

[44] B.M. Evans, and E. H. Chi, "Towards a model of understanding social search", In Proceedings of the 2008 ACM conference on Computer supported cooperative work, pp. 485-494, Nov 2008. https://doi.org/10.1145/1460563.1460641

[45] A. Rathore and P. Ilavarasan, "Pre- and post-launch emotions in new product development: Insights from twitter analytics of three products", International Journal of Information Management, vol. 50, pp. 111-127, 2020. Available: https://doi.org/10.1016/j.ijinfomgt. 2019.05.015

[46] Y. Yang, Z. Li, Y. Su, S. Wu and B. Li, "Customers as Co-Creators: Antecedents of Customer Participation in Online Virtual Communities, "International Journal of Environmental Research and Public Health, vol. 16, no.24, 4998, 2019. https://doi.org/10.3390/ijerph16244998

[47] J. Gallaugher and S. Ransbotham, Social media and customer dialog management at Starbucks. MIS Quarterly Executive, Vol. 9 No.4, pp. 197-211, 2010

[48] R. Rishika, A. Kumar, R. Janakiraman and R. Bezawada, "The Effect of Customers' Social Media Participation on Customer Visit Frequency and Profitability: An Empirical Investigation", Information Systems Research, vol. 24, no. 1, pp. 108-127, 2013. Available: 10.1287/isre.1120.0460 https://doi.org/10.1287/isre.1120.0460

[49] T. Aichner and F. Jacob, "Measuring the Degree of Corporate Social Media Use", International Journal of Market Research, vol. 57, no. 2, pp. 257-276, 2015. Available: 10.2501/ijmr-2015-018. https://doi.org/10.2501/ijmr-2015-018 
[50] J. Chen n.d. [Online]. https://sproutsocial.com/insights/social-customer-care/ Available Accessed: 19- Feb- 2020]

[51] A. M. Kaplan, "User participation within virtual worlds", In Mass Customization, pp. 333351, 2011, Springer, London. https://doi.org/10.1007/978-1-84996-489-0_16

[52] A. Kaplan and M. Haenlein, "The fairyland of Second Life: Virtual social worlds and how to use them", Business Horizons, vol. 52, no. 6, pp. 563-572, 2009. Available: 10.1016/j.bushor.2009.07.002. https://doi.org/10.1016/j.bushor.2009.07.002

[53] P.P. Correia and I. G Medina, I. G., "Digital social media: An interactive technology incorporated as a competitive advantage for business", International Journal of Interactive Mobile Technologies (iJIM), vol. 8 no. 2, pp. 23-27, 2014. https://doi.org/10.3991/ijim. $\underline{\mathrm{v} 8 \mathrm{i} 2.3576}$

[54] I. G. Medina and P. A. Pereira, "The importance of social media for commerce. A case study in Madeira Portugal", International Journal of Interactive Mobile Technologies (iJIM), vol. 6 no.1, pp. 37-42, 2012. https://doi.org/10.3991/ijim.v6i1.1825

\section{Author}

Sonica Rautela is a young professional working as an Assistant Professor at Symbiosis Centre for Management Studies, Pune, India. She is currently pursuing her doctoral degree from Symbiosis International (Deemed University) Pune, Maharashtra, India. Her interest areas include Social Media, New Product Development, Service Marketing, and Brand Management. She has also published research papers in reputed journals. She can be contacted at sonicaonnet@gmail.com.

Article submitted 2020-08-31. Resubmitted 2020-10-18. Final acceptance 2020-10-18. Final version published as submitted by the authors. 